\title{
4 断熱施工用ダウンライトの開発
}

消部茂明小往重夫因代茂樹

（松下筆工怢式会社）

1.はじめに

最近、省エネルギーと防音効果を问上させるととから天非に断熱材を牧きつめる倾问か 一般的となり、ダゥンライトも広く显及してきたため、断熟施的された天井にダウンライ トが取付けられる頻度か高くなってきた。断熱施工された天非は一般の天非と異なり、ダ ウンライトにとって故しい条作となり施工力法によっては火災の恐机が生じるっそてで、

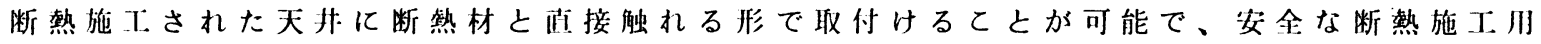
ダウンライトの間を発を行った絬果を報告する。

\section{2. 断熱施工の問題点}

断熟施工された天非にそのまま一般名ウンライトを取付けると次のような現象が生じる。

(1) 器!!代体の放熟孔を塞いでしまうため、ランプからの幅射熱が放熱されず本体外夙 满度加 $100{ }^{\circ} \mathrm{C}$ 以上なる。

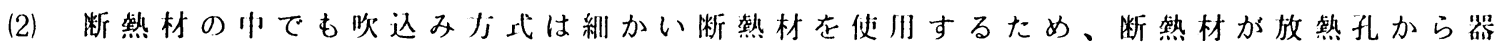
具队に進人する。

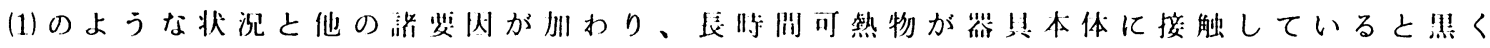

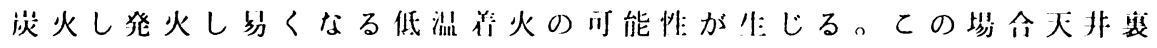

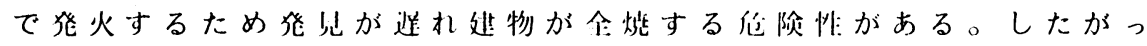

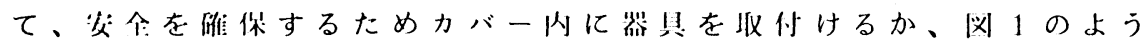

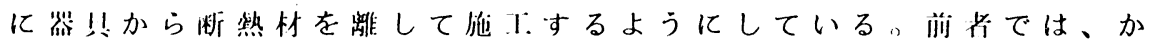

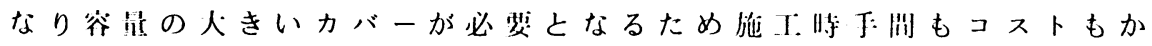

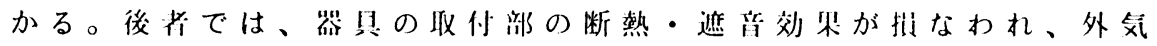

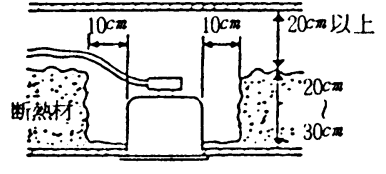

汶 1

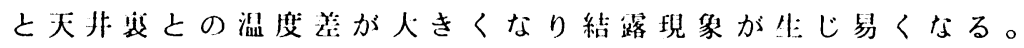

\section{3. 断熱施工用ダゥンライトの特徽}

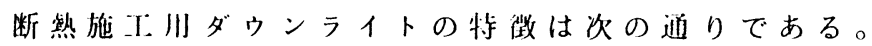

(1) ランプの㬏射熟を天非留に放射させない槛造である。

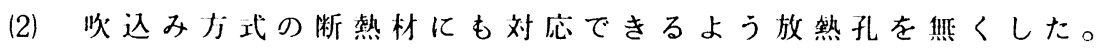

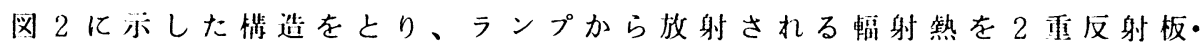

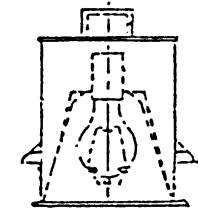

図 2

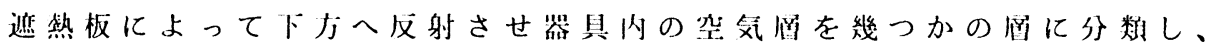

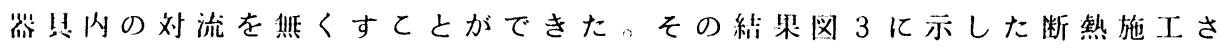

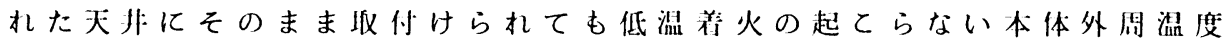

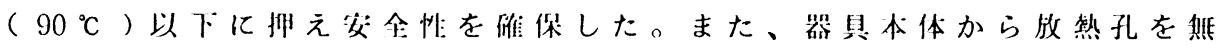
くし、端子台カバーを施け、率熟材の器具内・充電部への進人を防いだ。

4. おわりに

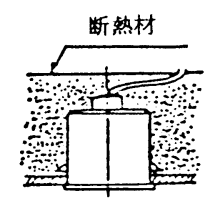

阙 3

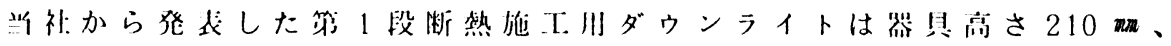

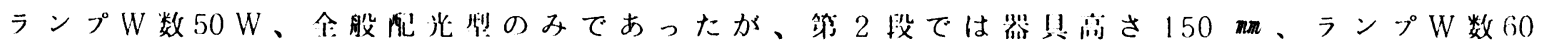
W、全般・集光・ウォールゥッシャ型と川途に令せて伐川できるよう品煫えした。今後は

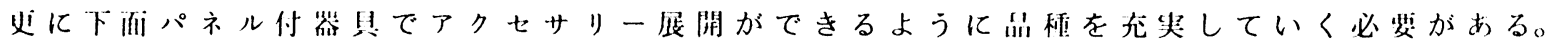

Development of The Downlight for Thermal insulation works . Sigeaki Nambu. Shigeo Ko jima. Shigeki Okudai 